\title{
Protein Arginine N-Methyltransferase 1
}

National Cancer Institute

\section{Source}

National Cancer Institute. Protein Arginine N-Methyltransferase 1. NCI Thesaurus. Code C134687.

Protein arginine $\mathrm{N}$-methyltransferase 1 (361 aa, $\sim 42 \mathrm{kDa}$ ) is encoded by the human PRMT 1 gene. This protein plays a role in the methylation of the guanidino nitrogens of arginyl residues in substrate proteins. 